\title{
Recent advances in understanding and managing
}

\section{resistant/refractory hypertension [version 1; peer review: 2}

\section{approved]}

\author{
Michael Doumas ${ }^{1,2}$, Konstantinos P Imprialos¹, Manolis S Kallistratos (iD), \\ Athanasios J Manolis ${ }^{3}$ \\ 12nd Propedeutic Department of Internal Medicine, Aristotle University of Thessaloniki, Thessaloniki, Makedonia, 54250, Greece \\ 2VAMC and George Washington University, Washington, USA \\ ${ }^{3}$ Cardiology, Asklepeion General Hospital, Athens, Attiki, 16673, Greece
}

V1 First published: 09 Mar 2020, 9(F1000 Faculty Rev):169

https://doi.org/10.12688/f1000research.21669.1

Latest published: 09 Mar 2020, 9(F1000 Faculty Rev):169

https://doi.org/10.12688/f1000research.21669.1

\section{Abstract}

The management of resistant hypertension presents several challenges in everyday clinical practice. During the past few years, several studies have been performed to identify efficient and safe pharmacological and non-pharmacological options for the management of such patients. The Spironolactone versus placebo, bisoprolol, and doxazosin to determine the optimal treatment for drug-resistant hypertension (PATHWAY-2) trial demonstrated significant benefits with the use of spinorolactone as a fourth-line drug for the treatment of resistant hypertension over doxazosin and bisoprolol. In addition, recent data support that spironolactone may demonstrate superiority over central acting drugs in such patients, as well. Based on the European guidelines, spironolactone is recommended as the fourth-line drug option, followed by amiloride, other diuretics, doxazosin, bisoprolol or clonidine. Among several device-based approaches, renal sympathetic denervation had fallen into hibernation after the disappointing results of the Renal Denervation in Patients With Uncontrolled Hypertension (SYMPLICITY HTN) 3 trial. However, the technique re-emerged at the epicenter of the clinical and research interest after the favorable results of three sham-controlled studies, which facilitated novel catheters and techniques to perform the denervation. Significant results of iliac anastomosis on blood pressure levels have also been demonstrated. Nevertheless, the technique-related adverse events resulted in withdrawal of this interventional approach. Last, the sympatholytic properties of the carotid baroreceptor activation therapy were associated with significant blood pressure reductions in patients with resistant hypertension, which need to be verified in larger controlled trials. Currently device-based approaches are recommended only in the setting of clinical trials until more safety and efficacy data become

\section{Open Peer Review}

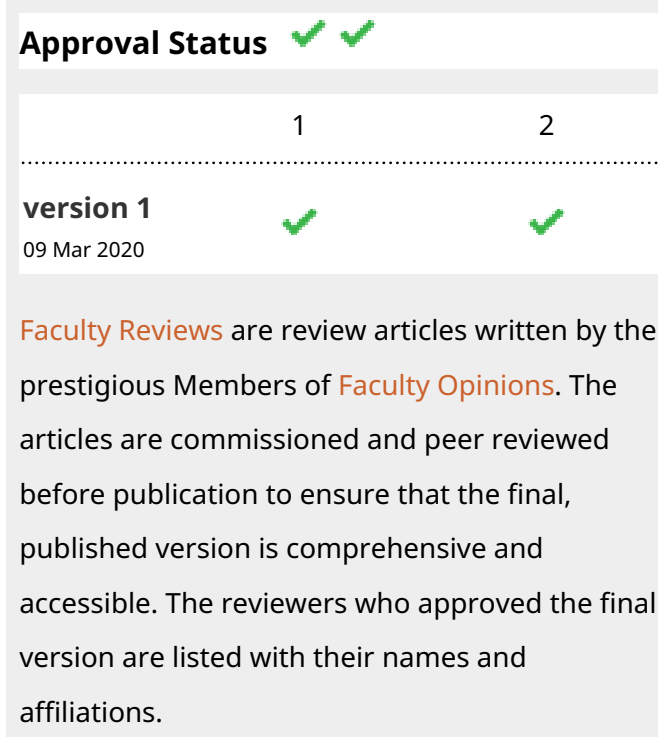

1. David Calhoun, University of Alabama at

Birmingham, Birmingham, USA

2. George Bakris, University of Chicago

Medicine, Chicago, USA

Any comments on the article can be found at the end of the article. 
available.

Keywords

resistant hypertension, spironolactone, doxazosin, bisoprolol,

clonidine, renal sympathetic denervation, iliac anastomosis, carotid

baroreceptor activation therapy

Corresponding author: Athanasios J Manolis (ajmanol@otenet.gr)

Author roles: Doumas M: Writing - Original Draft Preparation, Writing - Review \& Editing; Imprialos KP: Writing - Original Draft

Preparation; Kallistratos MS: Writing - Review \& Editing; Manolis AJ: Conceptualization, Writing - Review \& Editing

Competing interests: No competing interests were disclosed.

Grant information: The author(s) declared that no grants were involved in supporting this work.

Copyright: ( 2020 Doumas $\mathrm{M}$ et al. This is an open access article distributed under the terms of the Creative Commons Attribution License, which permits unrestricted use, distribution, and reproduction in any medium, provided the original work is properly cited.

How to cite this article: Doumas M, Imprialos KP, Kallistratos MS and Manolis AJ. Recent advances in understanding and managing resistant/refractory hypertension [version 1; peer review: 2 approved] F1000Research 2020, 9(F1000 Faculty Rev):169 https://doi.org/10.12688/f1000research.21669.1

First published: 09 Mar 2020, 9(F1000 Faculty Rev):169 https://doi.org/10.12688/f1000research.21669.1 


\section{Introduction}

The prevalence of resistant hypertension ranges from 5 to $30 \%$ on the basis of the definition used by relevant studies ${ }^{1}$. However, the true prevalence of resistant hypertension after applying a strict definition and having excluded causes of pseudo-resistant hypertension is less than $10 \%$ of the patients with treated hypertension ${ }^{1}$. Importantly, resistant hypertension is related with higher risk for cardiovascular morbidity and mortality, chronic kidney disease, and other hypertension-mediated target organ damage ${ }^{2}$.

Based on the European guidelines, resistant hypertension is defined as the failure to reduce systolic or diastolic blood pressure (BP) levels (or both) below 140 and $90 \mathrm{~mm} \mathrm{Hg}$, respectively, despite treatment with optimal doses (or best-tolerated doses) of an appropriate therapeutic strategy with the triple combination of an angiotensin-converting enzyme inhibitor or an angiotensin receptor blocker with a calcium channel blocker and a thiazide/ thiazide-type diuretic. As stated in the guidelines, home or ambulatory $\mathrm{BP}$ measurements should be used to confirm inadequate BP control, and exclusion of pseudo-resistant hypertension and secondary hypertension is mandatory to establish the diagnosis ${ }^{1}$.

In the previous European guidelines (2013), the use of mineralocorticoid receptor antagonists, amiloride, and the alpha1 blocker doxazosin were considered for the management of resistant hypertension ${ }^{3}$. During the past few years, several studies in resistant hypertension, and especially the spironolactone versus placebo, bisoprolol, and doxazosin to determine the optimal treatment for drug-resistant hypertension (PATHWAY-2) trial $^{4}$, resulted in changes in the recommendations for the management of resistant hypertension. Specifically, the addition of "low-dose spironolactone to existing treatment, or the addition of further diuretic therapy if intolerant to spironolactone, with either eplerenone, amiloride, higher-dose thiazide/thiazide-like diuretic or a loop diuretic, or the addition of bisoprolol or doxazosin" is now recommended ${ }^{1}$. Similarly, the consensus document of the American Heart Association for the management of resistant hypertension recommends the use of either spironolactone or eplerenone as a fourth-line agent, followed by a beta-blocker, a dual beta- and alpha-blocker, clonidine, or diltiazem ${ }^{5}$. The purposes of this review are to report and critically discuss the findings of recent studies that resulted in a stronger recommendation for the treatment of resistant hypertension and to report treatments under investigation that could prove to be useful in such patients.

\section{Exclusion of pseudo-resistant hypertension}

The exclusion of pseudo-hypertension is of paramount importance for the establishment of an accurate diagnosis. BP is often measured inaccurately; wrong-sized cuffs, measurement of BP only once, placement the cuff over the patient's clothes, and wrong position of the patient are common mistakes performed in everyday clinical practice ${ }^{1}$. A 2016 study demonstrated that readings performed in a routine triage setting were higher than the readings performed by trained physicians and resulted in a misdiagnosis of uncontrolled resistant hypertension in $33 \%$ of the patients ${ }^{6}$. Under-treatment is also a common cause of pseudoresistant hypertension, and studies indicate that a lack of BP control is often attributable to the absence of treatment intensification ${ }^{7}$.

Another important cause of pseudo-resistant hypertension is poor medication adherence. The recent Renal Sympathetic Denervation as a New Treatment for Therapy Resistant Hypertension (SYMPATHY) trial examined drug adherence with the detection of drug concentrations in blood samples in patients with uncontrolled hypertension on three or more anti-hypertensive drugs or with documented intolerance to two or more of the four major anti-hypertensive drug classes; $16 \%$ were non-adherent and $52 \%$ were poorly adherent ${ }^{8}$.

\section{Exclusion of other causes contributing to resistant hypertension}

Lifestyle factors such as excessive alcohol and salt intake contribute to the presence of resistant hypertension. Large amounts of alcohol consumption (three or more drinks per day) have an important dose-related effect on BP levels in both normotensive and hypertensive patients ${ }^{9}$. Abstinence in heavy alcohol drinkers may decrease 24 hours systolic and diastolic ambulatory BP levels by up to 7.2 and $6.6 \mathrm{~mm} \mathrm{Hg}$, respectively ${ }^{10}$. Usually, patients with resistant hypertension present an average sodium intake that exceeds $10 \mathrm{~g}$ per day ${ }^{11}$. Salt not only increases BP levels but also blunts the anti-hypertensive effect of the BP-lowering drugs $^{12}$. In salt-sensitive patients (elders, African-Americans, and patients with chronic kidney disease), these effects are much more pronounced $^{13}$. Moreover, obesity and increased body mass index in general increase significantly BP levels ${ }^{1}$. The mechanisms that induce hypertension in those patients include the activation of sympathetic nervous system and renin-angiotensinaldosterone system and also insulin resistance and impaired sodium excretion ${ }^{14}$. The adoption of current European Society of Cardiology/European Society of Hypertension guidelines on lifestyle changes may significantly decrease BP levels in those patients and contribute to BP control.

Finally, several drugs and substances may increase BP levels. Non-steroidal anti-inflammatory drugs (NSAIDs) represent probably the most common agents in terms of worsening BP control ${ }^{1}$. The use of NSAIDs not only increases BP levels but also can blunt the effect of various anti-hypertensive drugs such as diuretics, angiotensin-converting enzyme inhibitors, and angiotensin receptor blockers ${ }^{1}$. The hypertensive effect of NSAIDs is more pronounced in patients with chronic kidney disease ${ }^{1}$. Other substances that can increase BP levels are decongestants and stimulant agents used for weight loss and also contraceptives, cyclosporine, erythropoietin, and cortisone that increase BP levels mainly through fluid retention. A proposed work-up for patients with resistant hypertension is shown in Figure 1.

\section{Recent advances in pharmacological therapy}

Data from clinical studies of spironolactone versus adrenergic blockers

The landmark PATHWAY-2 study found significant benefits with the use of spironolactone in patients with resistant hypertension on a standard three-drug therapy with an angiotensinconverting enzyme inhibitor or an angiotensin receptor blocker, 
Exclude pseudoresistant hypertension and confirm blood pressure levels and

adherence to treatment

$\downarrow$

Identify contributing lifestyle factors

$\downarrow$

Rule out secondary causes of hypertension

$\downarrow$

Modify treatment according to patient characteristics using optimal doses of

appropriate medications

Figure 1. Proposed work-up for patients with resistant hypertension.

amlodipine, and indapamide ${ }^{4}$. The study was a double-blind four-way crossover study that assessed the use of spironolactone (25 or $50 \mathrm{mg}$ ) versus bisoprolol (5 to $10 \mathrm{mg}$ ), doxazosin ( 5 to $10 \mathrm{mg}$ ), or placebo. To exclude non-adherence, the study was monitored with pill count and measurement of serum angiotensin-converting enzyme activity. Spironolactone was superior to both active treatments and placebo, and mean reductions in $\mathrm{BP}$ were $8.70,4.48$, and $4.03 \mathrm{~mm} \mathrm{Hg}$ with spironolactone, bisoprolol, and doxazosin, respectively. Importantly, about $60 \%$ of the spironolactone users achieved BP control versus $43.3 \%$ of the bisoprolol and $41.5 \%$ of the doxazosin users ${ }^{4}$.

Apart from the beneficial effect of spironolactone in patients with resistant hypertension, the PATHWAY-2 study offered three important findings. First, despite the superiority of spironolactone over bisoprolol and doxazosin, the use of the latter two drugs was associated with significant reductions in BP compared with placebo. Thus, the European guidelines recommend the use of bisoprolol and doxazosin for the treatment of resistant hypertension when spironolactone is contraindicated or not tolerated ${ }^{1}$. Second, uptitration of spironolactone dose from 25 to $50 \mathrm{mg}$ resulted in a greater reduction in BP at week 12 of the study. The BP-lowering effect of spironolactone uptitration was higher compared with the corresponding increases in the dose of either bisoprolol or doxazosin $(-3.86 \mathrm{~mm} \mathrm{Hg}$ with spironolactone versus $-0.88 \mathrm{~mm} \mathrm{Hg}$ for doxazosin, $-1.49 \mathrm{~mm} \mathrm{Hg}$ for bisoprolol, and $-0.68 \mathrm{~mm} \mathrm{Hg}$ for placebo). Last, while spironolactone reduced BP levels irrespective of renin levels, an enhanced benefit in patients with suppressed renin levels was observed, and there was up to a $20 \mathrm{~mm} \mathrm{Hg}$ reduction in home $\mathrm{BP}$ in patients with the lowest renin levels ${ }^{4}$.
Important clinical information for the management of resistant hypertension arose from three recent substudies of the PATHWAY-2 trial. In the first substudy, the plasma aldosterone, renin, and aldosterone-to-renin ratio were assessed as predictors of home systolic BP response in 126 patients. Plasma aldosterone-to-renin ratio and plasma renin levels were found to be predictors of $\mathrm{BP}$ response to spironolactone. In the second one, the impact of each drug on the thoracic fluid content (an index of fluid retention) and vascular resistance was examined (226 patients). Thoracic fluid content was significantly reduced (by 6.8\%) from baseline with spironolactone but not with the other active treatments. Given the overall outcomes of the PATHWAY-2 study, this finding supports the theory that patients with resistant hypertension are characterized by volume overload, secondary to aldosterone excess, explaining the greater benefits observed with spironolactone $^{1}$. In the third substudy, the effect of amiloride on systolic BP was examined in a 6- to 12-week open-label runout phase, in which patients on spironolactone were crossed over from spironolactone to amiloride (146 patients). Amiloride use resulted in a remarkable reduction in BP levels of $20.4 \mathrm{~mm}$ $\mathrm{Hg}$, comparable to the $18.3 \mathrm{~mm} \mathrm{Hg}$ observed with spironolactone, suggesting that amiloride might be an effective alternative agent for these patients. Based on these findings, the European guidelines propose the use of amiloride as an alternative option if spironolactone is contraindicated or not well tolerated ${ }^{15}$.

Data from clinical studies of spironolactone versus central acting drugs

Although concrete evidence supports the superiority of mineralocorticoid receptor antagonists over alpha- and beta-blockers for patients with resistant hypertension, there is a lack of 
evidence regarding the use of central acting drugs in such patients. In this setting, the recent Resistant Hypertension Optimal Treatment (ReHOT) study compared the impact of spironolactone and clonidine in 187 patients with resistant hypertension ${ }^{16}$. BP control assessed with office and 24-hour ambulatory BP monitoring was similar across the two groups of patients. However, the 24-hour systolic and diastolic BP reduction and the daytime diastolic BP reductions observed with spironolactone were significantly greater than those observed with clonidine. Given the easier dosage scheme of spironolactone and the greater benefits in various ambulatory BP parameters, spironolactone seems to be a preferable option over clonidine ${ }^{17}$.

\section{Meta-analytic data of mineralocorticoid antagonists versus} other drug classes

Important information emerged from meta-analytic data for the use of mineralocorticoid receptor antagonists in patients with resistant hypertension. In 869 patients from four trials, spironolactone as add-on therapy was associated with a reduction in BP of $16.67 / 6.11 \mathrm{~mm} \mathrm{Hg}^{16}$. A meta-analysis of 662 patients and five trials found that the addition of spironolactone in patients with resistant hypertension resulted in a reduction in office BP levels of 15.73/6.21 mm Hg compared with placebo, but compared with other drugs (beta-blocker, candesartan, or alpha methyldopa), spironolactone reduced home systolic BP by $4.5 \mathrm{~mm} \mathrm{Hg}^{18}$. In a meta-analysis of five studies and 553 patients with resistant hypertension, spironolactone reduced 24-hour, daytime, nighttime, and office BP by 10.50/4.09, 10.20/4.14, 10.02/3.21, and $16.99 / 6.18 \mathrm{~mm} \mathrm{Hg}$, respectively ${ }^{19}$. Last, a meta-analysis of five studies and 755 patients with resistant hypertension found a greater reduction in systolic BP levels of $7.4 \mathrm{~mm} \mathrm{Hg}$ (in the randomized studies) and $11.9 \mathrm{~mm} \mathrm{Hg}$ (in the nonrandomized studies) with mineralocorticoid receptor antagonists compared with other fourth-line options (bisoprolol, doxazosin, furosemide, or other renin-angiotensin system blockers $)^{20}$.

Collectively, accumulating evidence suggests that mineralocorticoid receptor antagonists are the optimal choice as the fourth-line option in patients with resistant hypertension, and data favor their use over central acting drugs, alpha- and betablockers. Most data come from studies with spironolactone. However, eplerenone may be considered as an alternative when adverse effects (such as gynecomastia or vaginal bleeding) are observed with spironolactone therapy ${ }^{21}$, although strong data with eplerenone use are currently missing. Given the substantial fluid retention observed in these patients and the findings of the PATHWAY-2 study, amiloride is an alternative option, while treatment with doxazosin, bisoprolol, or clonidine may also be considered when either mineralocorticoid receptor antagonists or amiloride is contraindicated or adverse events occur.

\section{Interventional options for resistant hypertension}

Interventional approaches represent a novel potential addition on lifestyle interventions and pharmacological therapy for the management of resistant hypertension. The neurogenic mechanisms implicated in BP elevation have been the target of several interventional approaches such as renal sympathetic denervation (RSD) and carotid baroreceptor activation therapy ${ }^{22-24}$. The resistance of the arterial tree walls is another important factor contributing to the rise of BP. Recently, the creation of arteriovenous anastomosis between the distal iliac vein and artery to add a low resistance compartment to the arterial tree was investigated in patients with resistant hypertension ${ }^{25}$.

\section{Renal sympathetic denervation}

The early RSD studies SYMPLICITY HTN $-1^{26}$ and $-2^{27}$ showed impressive reductions in $\mathrm{BP}$ and created high expectations for the future of the procedure in the hypertension treatment field. However, the first randomized sham-controlled study (SYMPLICITY HTN-3) failed to show any significant benefits of RSD over sham control in the reduction of both office and ambulatory BP in patients with drug-resistant hyperten$\operatorname{sion}^{28}$, and the technique fell into hibernation. Although several pitfalls were identified, the incomplete denervation and lack of circumferential, four-quadrant sympathetic fiber interruption were the main factors pointed out as causes of the negative findings of the study ${ }^{29}$. Three recent randomized sham-controlled studies used improved technologies and techniques to achieve optimal renal denervation and offered encouraging results.

The first one was the SPYRAL HTN-OFF MED trial, a randomized sham-controlled study of patients with untreated hypertension. Patients were randomly assigned to RSD of all accessible renal arterial vessels with the Symplicity Spyral multi-electrode catheter or the Symplicity G3 S $(n=38)$ or a sham procedure $(n=42)$. After 3 months, RSD resulted in significantly greater reductions in office and ambulatory BP levels compared with those of the sham control group (BP reduction differences of $-7.7 /-4.9 \mathrm{~mm} \mathrm{Hg}$ and $-5.0 /-4.4 \mathrm{~mm} \mathrm{Hg}$ in office and ambulatory BP, respectively). Importantly, no patient reported any safety concerns ${ }^{30}$. Similar results were observed in the SPYRAL HTN-ON MED trial, a randomized sham control study (of patients with uncontrolled hypertension on one to three anti-hypertensive drugs) that used the same techniques described for SPYRAL-OFF MED. RSD resulted in a greater reduction in office and ambulatory BP compared with the sham technique group (BP reduction differences of $-6.8 /-3.5 \mathrm{~mm} \mathrm{Hg}$ and $-7.4 /-4.1 \mathrm{~mm} \mathrm{Hg}$ in office and ambulatory BP, respectively). No reports of renal artery stenosis or worsening of renal function were reported ${ }^{31}$. The RADIANCEHTN SOLO study was the third study that examined whether RSD performed with endovascular ultrasound reduces ambulatory $\mathrm{BP}$ in patients with hypertension in the absence of anti-hypertensive medication. After 2 months, significantly greater decreases in BP of $-6.5 /-4.1,-4.1 /-1.8$, and $-7.1 /-3.6 \mathrm{~mm} \mathrm{Hg}$ in office, ambulatory, and home BP were reported with RSD compared with the sham control group ${ }^{32}$.

A recent study assessed the efficacy of different ablation methods in reducing $\mathrm{BP}^{33}$. Particularly, patients with resistant hypertension were assigned to either treatment with radiofrequency RSD of the main renal arteries, side branches, and accessories or an endovascular ultrasound-based RSD of the main renal artery. After 3 months, BP levels were significantly more reduced in the ultrasound ablation group compared with the radiofrequency ablation group of the main renal artery $(-13.2 \pm 13.7$ versus $-6.5 \pm 10.3 \mathrm{~mm} \mathrm{Hg}$, respectively). Importantly, no significant 
difference was found between the radiofrequency ablation groups $(-8.3 \pm 11.7 \mathrm{~mm} \mathrm{Hg}$ in the additional side branch ablation) or between the ultrasound and the side branch ablation groups, suggesting potential superiority of ultrasound over radiofrequency ablation of the main artery in reducing BP levels ${ }^{33}$. However, larger studies are needed to confirm or dispute the superiority of one technique over the other. Up to then, no approach could be considered the preferred or first-choice option.

Collectively, these studies resurfaced the clinical and research interest for RSD in the management of resistant hypertension. Although more patients demonstrated BP reduction with RSD than with the sham procedure, in several study participants who underwent RSD, an increase in BP was noticed, suggesting that some patients are not eligible for RSD. The quest of patient eligibility requires the identification of reliable and accurate predictors of BP response, a very demanding step with unknown outcome. Studies with larger study populations and longer follow-up periods are needed to establish the safety and efficacy of the technique, and several such studies are either planned or being conducted. The results of these studies will either re-enforce the concept of RSD or put the final nail in the coffin of this interventional approach.

\section{Iliac vein and artery anastomosis}

The ROX CONTROL HTN study randomly assigned 83 patients with resistant hypertension to either pharmacological treatment plus placement of an arteriovenous coupler or pharmacological therapy alone. After 6 months, significant reductions in office and ambulatory systolic BP of 26.9 and $13.5 \mathrm{~mm} \mathrm{Hg}$ were noted with the anastomosis device group, respectively. In contrast, such benefits were not observed in the control group (3.7 and $0.5 \mathrm{~mm}$ $\mathrm{Hg}$, respectively). Similarly, a significant reduction in diastolic $\mathrm{BP}$ was reported with the device. However, implantation of the arteriovenous coupler was associated with ipsilateral venous stenosis in $29 \%$ of the patients, who received venoplasty or stenting ${ }^{34}$. After 12 months, office BP and ambulatory BP were reduced by $25 / 20.8$ and $12.6 / 15.3 \mathrm{~mm} \mathrm{Hg}$, respectively, suggesting that the technique might offer long-lasting benefits in BP levels. Nevertheless, the percentage of patients who presented venous stenosis increased to $33 \%$, who were treated successfully with venous stenting ${ }^{35}$. In conclusion, although iliac anastomosis showed promise in terms of efficacy, the safety concerns were significant and this approach was recently abandoned.

\section{Carotid baroreceptor activation therapy}

Carotid baroreceptor activation therapy is a device-based approach aiming to activate the baroreceptors that signal the brain to activate a sympatholytic response. Such approaches might be useful in conditions characterized by sympathetic overactivity, such as hypertension, heart failure, and arrhythmias ${ }^{36,37}$. The potential benefits might be due to the reduction of heart rate (and thus cardiac workload and energy demands) and the manifestation of arterial dilation, which results in reduction of the peripheral resistance and enhancement of renal blood flow and natriuresis.

The Rheos Pivotal Trial assessed the impact of the Rheos system, a device that uses electrical impulses from a pulse generator to chronically activate the baroreflex at the carotid sinus, on BP levels in 265 patients with resistant hypertension. In the first group of patients, treatment was applied for the first 6 months, whereas in the second group, a delayed treatment initiation was implemented at the 6-month visit; $42 \%$ of patients in the first group versus $24 \%$ in the second group achieved systolic BP of less than $140 \mathrm{~mm} \mathrm{Hg}$ at 6 months, and more than $50 \%$ in both groups had a systolic BP of less than $140 \mathrm{~mm} \mathrm{Hg}$ at 12 months. However, the procedural safety endpoints of the study were not met since procedural complications occurred in $25 \%$ of the patients (transient or permanent nerve injury or general surgical complications $)^{38}$.

However, the same company developed a second-generation device of smaller size, the Barostim Neo, which uses a smaller electrode on the surface of only one of the sinuses, thus reducing the invasiveness of the procedure and extending the battery life and replacement period ${ }^{39}$. The Barostim Neo System in the Treatment of Heart Failure/Barostim Hope for Heart Failure and the recent Baroreflex Activation Therapy in Patients with Heart Failure and a Reduced Ejection Fraction trials ${ }^{40,41}$ demonstrated significant benefits in the functional status, quality of life, and exercise capacity in patients with heart failure and reduced injection fraction. Importantly, these studies met the safety endpoints; thus, the device was granted approval by the US Food and Drug Administration $^{39}$. The device has also been approved in Europe for the management of resistant hypertension; the Barostim Neo trial demonstrated a persistent reduction in BP after 6 months (of a systolic BP of approximately $26 \mathrm{~mm} \mathrm{Hg}$ ) and an adequate safety profile $\mathrm{e}^{39,42}$.

Overall, baroreflex activation therapy is approved for the treatment of resistant hypertension in Europe and for the treatment of heart failure with reduced ejection fraction in the US. However, it is more invasive than RSD, the safety of the procedure is not unequivocally proven, and thus it has not gained either wide application or general acceptance by hypertensive experts for the management of resistant hypertension.

The MobiusHD carotid bulb expansion device is an underexamination device that is used to reduce BP through stretching of the carotid artery at the bulb, which in turn activates the carotid baroreceptors. The Controlling and Lowering Blood Pressure with the MOBIUSHD (CALM-FIM_EUR) study recently reported pronounced reduction in BP levels of 24/12 $\mathrm{mm} \mathrm{Hg}$ in office and $21 / 12 \mathrm{~mm} \mathrm{Hg}$ in ambulatory BP with the use of the MobiusHD device in patients with resistant hypertension ${ }^{43}$. Importantly, the device demonstrated an acceptable safety profile $^{43}$. Two other trials-the CALM-FIM_US ${ }^{44}$ and the Controlling and Lowering Blood Pressure with the MobiusHD $(\mathrm{CALM}-2)^{45}$ studies-are examining the use of the MobiusHD device in patients with resistant hypertension. The results of these studies are eagerly awaited to further clarify the efficacy and safety of this approach and strengthen its role in the management of resistant hypertension.

\section{Continuous positive airway pressure therapy and resistant hypertension}

Obstructive sleep apnea (OSA) is highly prevalent in patients with resistant hypertension ${ }^{46-51}$. It has been suggested that the increased fluid retention and consequent upper airway edema 
may explain the high prevalence of OSA in these patients ${ }^{52,53}$. In addition, central fluid accumulation during sleep seems to significantly contribute to the manifestation and worsening of $\mathrm{OSA}^{54-56}$. Treatment of OSA with continuous positive airway pressure (CPAP) in patients with resistant hypertension was found to induce a modest but significant reduction in BP levels. In a study of patients with resistant hypertension and OSA, CPAP treatment resulted in a reduction in ambulatory $\mathrm{BP}$ of $3.1 / 3.2 \mathrm{~mm} \mathrm{Hg}$, an effect that was even greater in patients more adherent to CPAP therapy (reduction in ambulatory BP of $4.4 / 4.1 \mathrm{~mm} \mathrm{Hg}$ with at least 4 hours of CPAP treatment per night $)^{57}$. In contrast, a favorable impact of CPAP treatment on the prevention of cardiovascular events has not yet been demonstrated ${ }^{58}$.

\section{Refractory hypertension}

The term refractory hypertension has been recently re-introduced and was included in the 2017 American guidelines for the management of hypertension ${ }^{59}$. Refractory hypertension is defined as failure of BP control with the use of five or more anti-hypertensive drugs of different drug classes, including a long-acting thiazide diuretic, such as chlorthalidone, and a mineralocorticoid receptor antagonist $\mathrm{t}^{59}$. This novel type of uncontrolled hypertension seems to be rare, affecting less than $5 \%$ of the patients referred to a specialized clinic for uncontrolled hypertension. Furthermore, refractory hypertension was found to be more frequent in African-American, younger, and female patients ${ }^{60-62}$. There is evidence suggesting that the cause of treatment failure in patients with refractory hypertension, in contrast to resistant hypertension, is the increased sympathetic tone, rather than fluid retention, as indicated by the increased heart rate levels and urine norepinephrine excretion in such patients ${ }^{60-62}$. Therefore, intensification of diuretic therapy may not be effective, and sympatholytic agents or device-based therapy may be preferable $e^{60-62}$. However, data in such patients are still missing and studies are needed to identify optimal management options.

\section{Conclusions}

During the past few years, important data for the management of resistant hypertension have emerged. Most data support that mineralocorticoid antagonists (and especially spironolactone) present more favorable BP-lowering properties in patients with resistant hypertension compared with central acting drugs, alpha- and beta-blockers. In case of contraindications or adverse events, amiloride should be used as an alternative option followed by doxazosin, bisoprolol, or clonidine.

Several device-based approaches are being investigated, and recent RSD trials have rekindled interest in the interventional therapy of resistant hypertension. The few studies implementing carotid baroreceptor stimulation have shown favorable results, which need to be verified in controlled trials with a long follow-up period, while safety concerns need to be adequately addressed. Iliac anastomosis devices are no longer available in our therapeutic armamentarium. Overall, we are living in exciting times in the resistant hypertension field, and a lot of data, especially about the role of interventional approaches in the treatment of resistant hypertension, are eagerly expected in the near future.
1. F Williams B, Mancia G, Spiering W, et al.: 2018 ESC/ESH Guidelines for the management of arterial hypertension. Eur Heart J. 2018; 39(33): 3021-104. PubMed Abstract | Publisher Full Text | F1000 Recommendation

2. Daugherty SL, Powers JD, Magid DJ, et al.: Incidence and prognosis of resistant hypertension in hypertensive patients. Circulation. 2012; 125(13): 1635-42. PubMed Abstract | Publisher Full Text | Free Full Text

3. Mancia G, Fagard R, Narkiewicz K, et al:: 2013 ESH/ESC guidelines for the management of arterial hypertension: the Task Force for the Management of Arterial Hypertension of the European Society of Hypertension (ESH) and of the European Society of Cardiology (ESC). Eur Heart J. 2013; 34(28): 2159-219. PubMed Abstract | Publisher Full Text

4. F Williams B, MacDonald TM, Morant S, et al:: Spironolactone versus placebo, bisoprolol, and doxazosin to determine the optimal treatment for drugresistant hypertension (PATHWAY-2): a randomised, double-blind, crossover trial. Lancet. 2015; 386(10008): 2059-68.

PubMed Abstract | Publisher Full Text | Free Full Text | F1000 Recommendation

5. F Carey RM, Calhoun DA, Bakris GL, et al:: Resistant Hypertension: Detection, Evaluation, and Management: A Scientific Statement From the American Heart Association. Hypertension. 2018; 72(5): e53-e90.

PubMed Abstract | Publisher Full Text | Free Full Text | F1000 Recommendation

6. Bhatt $\mathrm{H}$, Siddiqui $\mathrm{M}$, Judd $\mathrm{E}$, et al.: Prevalence of pseudoresistant hypertension due to inaccurate blood pressure measurement. J Am Soc Hypertens. 2016; 10(6): 493-9.

PubMed Abstract | Publisher Full Text | Free Full Text

7. Egan BM, Zhao Y, Li J, et al:: Prevalence of optimal treatment regimens in patients with apparent treatment-resistant hypertension based on office blood pressure in a community-based practice network. Hypertension. 2013; 62(4): $691-7$.

PubMed Abstract | Publisher Full Text | Free Full Text

8. $\mathrm{F}$ de Jager RL, van Maarseveen EM, Bots ML, et al.: Medication adherence in patients with apparent resistant hypertension: findings from the SYMPATHY trial. Br J Clin Pharmacol. 2018; 84(1): 18-24.

PubMed Abstract | Publisher Full Text | Free Full Text | F1000 Recommendation

9. Chobanian AV, Bakris GL, Black HR, et al.: Seventh report of the Joint National Committee on Prevention, Detection, Evaluation, and Treatment of High Blood Pressure. Hypertension. 2003; 42(6): 1206-52. PubMed Abstract | Publisher Full Text

10. Aguilera MT, de la Sierra A, Coca A, et al:: Effect of alcohol abstinence on blood pressure: assessment by 24 -hour ambulatory blood pressure monitoring. Hypertension. 1999; 33(2): 653-7. PubMed Abstract | Publisher Full Text

11. Nishizaka MK, Pratt-Ubunama M, Zaman MA, et al.: Validity of plasma aldosterone-to-renin activity ratio in African American and white subjects with resistant hypertension. Am J Hypertens. 2005; 18(6): 805-12.

PubMed Abstract | Publisher Full Text

12. He FJ, MacGregor GA: Effect of longer-term modest salt reduction on blood pressure. Cochrane Database Syst Rev. 2004; (3): CD004937. PubMed Abstract | Publisher Full Text

13. Boudville N, Ward S, Benaroia M, et al:: Increased sodium intake correlates with greater use of antihypertensive agents by subjects with chronic kidney disease. Am J Hypertens. 2005; 18(10): 1300-5. PubMed Abstract | Publisher Full Text

14. Manolis AJ, Poulimenos LE, Kallistratos MS, et al: Sympathetic overactivity in hypertension and cardiovascular disease. Curr Vasc Pharmacol. 2014; 12(1): 4-15.

PubMed Abstract | Publisher Full Text

15. F Williams B, MacDonald TM, Morant SV, et al:: Endocrine and haemodynamic changes in resistant hypertension, and blood pressure responses to spironolactone or amiloride: the PATHWAY-2 mechanisms substudies. Lancet Diabetes Endocrinol. 2018; 6(6): 464-75.

PubMed Abstract | Publisher Full Text | Free Full Text | F1000 Recommendation 
16. F Krieger EM, Drager LF, Giorgi DMA, et al:: Spironolactone Versus Clonidine as a Fourth-Drug Therapy for Resistant Hypertension: The ReHOT Randomized Study (Resistant Hypertension Optimal Treatment). Hypertension. 2018; 71(4): 681-90.

PubMed Abstract | Publisher Full Text | F1000 Recommendation

17. F Zhao D, Liu H, Dong P, et al:: A meta-analysis of add-on use of spironolactone in patients with resistant hypertension. Int J Cardiol. 2017; 233 113-7.

PubMed Abstract | Publisher Full Text | F1000 Recommendation

18. $\mathrm{F}$ Liu L, Xu B, Ju Y: Addition of spironolactone in patients with resistan hypertension: A meta-analysis of randomized controlled trials. Clin Exp Hypertens. 2017; 39(3): 257-63.

PubMed Abstract | Publisher Full Text | F1000 Recommendation

19. Wang C, Xiong B, Huang J: Efficacy and Safety of Spironolactone in Patients with Resistant Hypertension: A Meta-analysis of Randomised Controlled Trials. Heart Lung Circ. 2016; 25(10): 1021-30. PubMed Abstract | Publisher Full Text

20. Sinnott SJ, Tomlinson LA, Root AA, et al:: Comparative effectiveness of fourthline anti-hypertensive agents in resistant hypertension: A systematic review and meta-analysis. Eur J Prev Cardiol. 2017; 24(3): 228-38.

PubMed Abstract| Publisher Full Tex

21. F Calhoun DA: Advances in resistant hypertension. Ann Transl Med. 2018; 6(15): 294

PubMed Abstract | Publisher Full Text | Free Full Text | F1000 Recommendation

22. F Schlaich MP: Renal Sympathetic Denervation: A Viable Option for Treating Resistant Hypertension. Am J Hypertens. 2017; 30(9): 847-56. PubMed Abstract | Publisher Full Text | F1000 Recommendation

23. F Bolignano D, Coppolino G: Baroreflex stimulation for treating resistant hypertension: ready for the prime-time? Rev Cardiovasc Med. 2018; 19(3): 89-95.

PubMed Abstract | Publisher Full Text | F1000 Recommendation

24. F Voora R, Hinderliter AL: Modulation of Sympathetic Overactivity to Treat Resistant Hypertension. Curr Hypertens Rep. 2018; 20(11): 92. PubMed Abstract | Publisher Full Text | F1000 Recommendation

25. F Schlaich MP, Azzam O, Sata Y: Hypertension on the ROX: Durable Blood Pressure Lowering With Central Iliac Arteriovenous Anastomosis. Hypertension. 2017; 70(6): 1084-6.

PubMed Abstract | Publisher Full Text | F1000 Recommendation

26. $\mathrm{F}$ Krum $\mathrm{H}$, Schlaich $\mathrm{M}$, Whitbourn $\mathrm{R}$, et al:: Catheter-based renal sympathetic denervation for resistant hypertension: a multicentre safety and proof-ofprinciple cohort study. Lancet. 2009; 373(9671): 1275-81.

PubMed Abstract | Publisher Full Text | F1000 Recommendation

27. F Symplicity HTN-2 Investigators, Esler MD, Krum H, et al.: Renal sympathetic denervation in patients with treatment-resistant hypertension (The Symplicity HTN-2 Trial): a randomised controlled trial. Lancet. 2010; 376(9756): 1903-9. PubMed Abstract | Publisher Full Text | F1000 Recommendation

28. F Bhatt DL, Kandzari DE, O'Neill WW, et al:: A controlled trial of renal denervation for resistant hypertension. N Engl J Med. 2014; 370(15): 1393-401. PubMed Abstract | Publisher Full Text | F1000 Recommendation

29. Papademetriou V, Stavropoulos K, Doumas M, et al:: Now That Renal Denervation Works, How Do We Proceed? Circ Res. 2019; 124(5): 693-5. PubMed Abstract | Publisher Full Text

30. F Townsend RR, Mahfoud F, Kandzari DE, et al.: Catheter-based renal denervation in patients with uncontrolled hypertension in the absence of antihypertensive medications (SPYRAL HTN-OFF MED): a randomised, sham controlled, proof-of-concept trial. Lancet. 2017; 390(10108): 2160-70. PubMed Abstract | Publisher Full Text | F1000 Recommendation

31. F Kandzari DE, Böhm M, Mahfoud F, et al:: Effect of renal denervation on blood pressure in the presence of antihypertensive drugs: 6-month efficacy and safety results from the SPYRAL HTN-ON MED proof-of-concept randomised trial. Lancet. 2018; 391(10137): 2346-55. PubMed Abstract | Publisher Full Text | F1000 Recommendation

32. F Azizi M, Schmieder RE, Mahfoud F, et al:: Endovascular ultrasound rena denervation to treat hypertension (RADIANCE-HTN SOLO): a multicentre, international, single-blind, randomised, sham-controlled trial. Lancet. 2018; 391(10137): 2335-45

PubMed Abstract | Publisher Full Text | F1000 Recommendation

33. F Fengler K, Rommel KP, Blazek S, et al:: A Three-Arm Randomized Trial of Different Renal Denervation Devices and Techniques in Patients With Resistant Hypertension (RADIOSOUND-HTN). Circulation. 2019; 139(5): 590-600. PubMed Abstract | Publisher Full Text | F1000 Recommendation

34. F Lobo MD, Sobotka PA, Stanton A, et al:: Central arteriovenous anastomosis for the treatment of patients with uncontrolled hypertension (the ROX CONTROL HTN study): a randomised controlled trial. Lancet. 2015; 385(9978): 1634-41.

PubMed Abstract | Publisher Full Text | F1000 Recommendation

35. F Lobo MD, Ott C, Sobotka PA, et al:: Central Iliac Arteriovenous Anastomosis for Uncontrolled Hypertension: One-Year Results From the ROX CONTROL HTN Trial. Hypertension. 2017; 70(6): 1099-105. PubMed Abstract | Publisher Full Text | F1000 Recommendation
36. F Devgun J, Jobanputra YB, Arustamyan M, et al:: Devices and interventions or the prevention of adverse outcomes of tachycardia on heart failure. Heart Fail Rev. 2018; 23(4): 507-16.

PubMed Abstract | Publisher Full Text | F1000 Recommendation

37. $\mathrm{F}$ van Kleef MEAM, Bates MC, Spiering W: Endovascular Baroreflex Amplification for Resistant Hypertension. Curr Hypertens Rep. 2018; 20(5): 46. PubMed Abstract | Publisher Full Text | Free Full Text | F1000 Recommendation

38. F Bisognano JD, Bakris G, Nadim MK, et al:: Baroreflex activation therapy lowers blood pressure in patients with resistant hypertension: results from the double-blind, randomized, placebo-controlled rheos pivotal trial. J Am Coll Cardiol. 2011; 58(7): 765-73.

PubMed Abstract | Publisher Full Text | F1000 Recommendation

39. F Lohmeier TE, Hall JE: Device-Based Neuromodulation for Resistant Hypertension Therapy. Circ Res. 2019; 124(7): 1071-93.

PubMed Abstract | Publisher Full Text | Free Full Text | F1000 Recommendation

40. Abraham WT, Zile MR, Weaver FA, et al.: Baroreflex Activation Therapy for the Treatment of Heart Failure With a Reduced Ejection Fraction. JACC Heart Fail. 2015; 3(6): 487-96.

PubMed Abstract | Publisher Full Text

41. Zile M, Lindenfeld J, Weaver FA, et al:: Baroreflex Activation Therapy (BAT) in Patients with Heart Failure and a Reduced Ejection Fraction (HFrEF): The BeAT-HF Trial. 2019

Reference Source

42. Hoppe UC, Brandt MC, Wachter R, et al:: Minimally invasive system fo baroreflex activation therapy chronically lowers blood pressure with pacemaker-like safety profile: results from the Barostim neo trial. J Am Soc Hypertens. 2012; 6(4): 270-6.

PubMed Abstract | Publisher Full Text

43. F Spiering W, Williams B, Van der Heyden J, et al:: Endovascular baroreflex amplification for resistant hypertension: a safety and proof-of-principle clinica study. Lancet. 2017; 390(10113): 2655-61.

PubMed Abstract | Publisher Full Text | F1000 Recommendation

44. ClinicalTrials.gov: Controlling and Lowering Blood Pressure With The MOBIUSHD'M (CALM-FIM_US). Accessed February 9, 2020.

Reference Source

45. ClinicalTrials.gov: CALM- 2 - Controlling and Lowering Blood Pressure With the MobiusHD'M (CALM-2). Accessed February 9, 2020.

Reference Source

46. Lloberes P, Lozano L, Sampol G, et al.: Obstructive sleep apnoea and 24-h blood pressure in patients with resistant hypertension. J Sleep Res. 2010; 19(4) 597-602.

PubMed Abstract | Publisher Full Text

47. Logan AG, Perlikowski SM, Mente A, et al:: High prevalence of unrecognized sleep apnoea in drug-resistant hypertension. J Hypertens. 2001; 19(12): $2271-7$

PubMed Abstract | Publisher Full Text

48. Min $\mathrm{HJ}$, Cho YJ, Kim CH, et al:: Clinical Features of Obstructive Sleep Apnea That Determine Its High Prevalence in Resistant Hypertension. Yonsei Med J. 2015; 56(5): 1258-65.

PubMed Abstract | Publisher Full Text | Free Full Text

49. Muxfeldt ES, Margallo VS, Guimarães GM, et al:: Prevalence and associated factors of obstructive sleep apnea in patients with resistant hypertension. $A m$ J Hypertens. 2014; 27(8): 1069-78.

PubMed Abstract | Publisher Full Tex

50. Walia $\mathrm{HK}, \mathrm{LiH}$, Rueschman $\mathrm{M}$, et al: Association of severe obstructive sleep apnea and elevated blood pressure despite antihypertensive medication use. J Clin Sleep Med. 2014; 10(8): 835-43.

PubMed Abstract | Publisher Full Text | Free Full Text

51. Pratt-Ubunama MN, Nishizaka MK, Boedefeld RL, et al:: Plasma aldosterone is related to severity of obstructive sleep apnea in subjects with resistant hypertension. Chest. 2007; 131(2): 453-9.

PubMed Abstract | Publisher Full Text

52. Di Murro A, Petramala L, Cotesta D, et al.: Renin-angiotensin-aldosterone system in patients with sleep apnoea: prevalence of primary aldosteronism. $J$ Renin Angiotensin Aldosterone Syst. 2010; 11(3): 165-72.

PubMed Abstract | Publisher Full Text

53. Prejbisz A, Florczak E, Klisiewicz A, et al.: Relationship between primary aldosteronism and obstructive sleep apnoea, metabolic abnormalities and cardiac structure in patients with resistant hypertension. Endokrynol Pol. 2013; 64(5): 363-7.

PubMed Abstract | Publisher Full Text

54. Friedman O, Bradley TD, Chan CT, et al:: Relationship between overnight rostral fluid shift and obstructive sleep apnea in drug-resistant hypertension. Hypertension. 2010; 56(6): 1077-82.

PubMed Abstract | Publisher Full Tex

55. Chiu KL, Ryan CM, Shiota S, et al.: Fluid shift by lower body positive pressure increases pharyngeal resistance in healthy subjects. Am J Respir Crit Care Med. 2006; 174(12): 1378-83.

PubMed Abstract | Publisher Full Text

56. Redolfi S, Arnulf I, Pottier M, et al.: Effects of venous compression of the legs on overnight rostral fluid shift and obstructive sleep apnea. Respir Physiol Neurobiol 2011; 175(3): 390-3.

PubMed Abstract | Publisher Full Text 
57. F Martínez-García MA, Capote F, Campos-Rodríguez F, et al: Effect of CPAP on blood pressure in patients with obstructive sleep apnea and resistant hypertension: the HIPARCO randomized clinical trial. JAMA. 2013; 310(22): 2407-15.

PubMed Abstract | Publisher Full Text | F1000 Recommendation

58. F McEvoy RD, Antic NA, Heeley E, et al:: CPAP for Prevention of Cardiovascular Events in Obstructive Sleep Apnea. N Engl J Med. 2016; 375(10): 919-31.

PubMed Abstract | Publisher Full Text | F1000 Recommendation

59. F Whelton PK, Carey RM, Aronow WS, et al:: 2017 ACC/AHA/AAPA/ABC/ACPM/ AGS/APhA/ASH/ASPC/NMA/PCNA Guideline for the Prevention, Detection, Evaluation, and Management of High Blood Pressure in Adults: A Report of the American College of Cardiology/American Heart Association Task Force on Clinical Practice Guidelines. Hypertension. 2018; 71(19): e127-e248. PubMed Abstract | Publisher Full Text | F1000 Recommendation

60. Dudenbostel T, Acelajado MC, Pisoni R, et al.: Refractory Hypertension: Evidence of Heightened Sympathetic Activity as a Cause of Antihypertensive Treatment Failure. Hypertension. 2015; 66(1): 126-33. PubMed Abstract | Publisher Full Text | Free Full Text

61. F Siddiqui M, Calhoun DA: Refractory versus resistant hypertension. Curr Opin Nephrol Hypertens. 2017; 26(1): 14-9.

PubMed Abstract | Publisher Full Text | F1000 Recommendation

62. F Velasco A, Siddiqui M, Kreps E, et al:: Refractory Hypertension Is not Attributable to Intravascular Fluid Retention as Determined by Intracardiac Volumes. Hypertension. 2018; 72(2): 343-9.

PubMed Abstract | Publisher Full Text | Free Full Text | F1000 Recommendation 


\section{Open Peer Review}

\section{Current Peer Review Status:}

\section{Editorial Note on the Review Process}

Faculty Reviews are review articles written by the prestigious Members of Faculty Opinions. The articles are commissioned and peer reviewed before publication to ensure that the final, published version is comprehensive and accessible. The reviewers who approved the final version are listed with their names and affiliations.

\section{The reviewers who approved this article are:}

\section{Version 1}

\section{George Bakris}

Department of Medicine, ASH Comprehensive Hypertension Center, University of Chicago Medicine, Chicago, IL, USA

Competing Interests: No competing interests were disclosed.

\section{David Calhoun}

Vascular Biology and Hypertension Program, University of Alabama at Birmingham, Birmingham, AL, USA

Competing Interests: No competing interests were disclosed.

The benefits of publishing with F1000Research:

- Your article is published within days, with no editorial bias

- You can publish traditional articles, null/negative results, case reports, data notes and more

- The peer review process is transparent and collaborative

- Your article is indexed in PubMed after passing peer review

- Dedicated customer support at every stage

For pre-submission enquiries, contact research@f1000.com 